\title{
HEALTH IN INDUSTRY
}

$I^{\mathrm{N}}$ a foreword to a publication issued by the Ministry of Labour, the Minister, Mr. John Hare, directs attention to the fact that more than 300 million working days are lost each year in Great Britain because of sickness or injury.

The Minister's foreword is contained in the booklet, Health at Work*, which gives fourteen examples of individual industrial health schemes operating successfully in factories in different parts of Great Britain. and the Minister hopes that these examples will encourage other firms to follow suit. The booklet is being widely distributed to factory occupiers by H.M. Factory Inspectorate. It deals with such questions as how factory medical services are organized, and what they achieve, the attitudes of workers to their introduction and the advantages derived by both employer and worker.

In carrying out the survey, the Ministry obtained from each factory details of the nature of the work done there, the organization of the medical services, the work of the medical officers and nursing staff, and the cost of each scheme. Four of the factories employ from 231 to 300 workers ; five employ from 500 to 1,000 ; three from 1,000 to 5,000 , and two more than 5,000. Included in the industries represented are heavy engineering and foundry work, copper and metal refining, the manufacturing of electric cookers, refrigerators, electro-plated ware, carbon black, printing machinery, animal feeding stuffs and vegetable oil. Also included are wool and worsted spinning, the processing of asbestos yarns and pipes, and the preparation of insecticides, fungicides, fine chemicals and pharmaceuticals.

Fear about costs is suggested as being the biggest single factor in preventing a more rapid spread of industrial health schemes. 'The booklet gives detailed figures of the cost of the schemes provided. The annual running costs vary widely according to the

* Ministry of Labour. Health at Work : a Description of Medical Services in Fourteen British Factories. Pp: 76. (London: Ministry of Labour, 1960.) nature of the services provided and the numbers employed. Of the 14 schemes described, seven cost $£ 2$ or less a head per annum, five cost between $£ 2$ and $£ 3$, and the other two more than $£ 3$. The booklet also mentions an attempt at another factory to weigh in terms of cash the worth or value of such a scheme. This led to the conclusion that, on a conservative estimate, the annual recurring costs of the medical scheme were more than covered by savings in time lost, and that the long-term benefits in better health and morale were a bonus alike to the company and the employee.

It is emphasized that the booklet does not intend to provide a ready-made pattern from which an employer can pick a scheme to suit his pocket, or the size of his factory and his business. What it does show is how, in practice, such schemes are operating to meet particular needs of particular firms, and the considerable variety of functions which the services can perform to the advantage of employers and workpeople. The reasons why firms considered it worth while to spend more money voluntarily on medical supervision varied according to the type of industry, but the following were typical: (1) the pre-employment examination was a safeguard to management and workers ; (2) from a practical point of view, speedy attention to accidents and illhealth saved time; (3) improvement in relations between employers and workers resulted from such a scheme.

The general impression drawn from reactions on the part of workers was that schemes of medical supervision described in the booklet provided a personal service which the workers greatly appreciated. The fact that immediate and expert attention could be given to the injured and sick aroused a feeling of confidence among them. The booklet indicates that in one or two instances there was some initial suspicion on the part of workers which soon disappeared with experience of the working of the schemes.

\section{ELM DISEASE}

\begin{abstract}
LTHOUGH the elms are not, nowadays, regarded A as important species in forestry proper, the Forestry Commissioners sometimes feel that it is incumbent on them to devote time and money to conduct research into problems concerned, with trees in which the British public as a whole are generally interested. A recent publication*, which would have been more correctly described as referring to southern England, deals with such a case. It is concerned with a fungous disease of elms caused by Ceratostomella ulmi (Schwartz) Buis., which was first recorded in France in 1918, and in Holland in 1919, and is suspected as having been introduced with elms imported from eastern Asia. It soon became widespread in northern Europe and in North America.
\end{abstract}

* Forestry Commizsion, 13ulletin No. 33: The Status and Devclopment of Elm Disease in Britain, By T. $\mathbf{~}$. Peace. Pp. iv $+44+76$
plates. (London: F.M. Stationery Office, 1960.) 10s, net.
It was first recorded in Fngland in 1927, by which time it was giving much concern to tree-growers in Holland, where its severity at one time carned for it the title of the Dutch elm disease. The effect of the fungus is to cause a vascular wilting of the leaves followed by the death of twigs and branches and even of whole trees. The unsightliness of the dead trees must have attracted the attention of all who travel through those counties where elms are such a notable feature of the landscape. The disease was probably present in Great Britain before its first recording.

The task of studying this disease and of keeping an eyo on it was entrusted by the Forestry Commission in 1928 to $\mathrm{Mr}$. T. R. Peace while he was stationed at the Imperial Forestry Institute, Oxford, and he has continued to do this since his appointment to the staff of the Commission, where he is now chief research officer. The present publication, issued by 